\title{
Waning antibody levels after vaccination with mRNA BNT162b2 and inactivated CoronaVac COVID-19 vaccines in Hong Kong blood donors
}

Shirley LL Kwok ${ }^{1,2}$, Samuel MS Cheng ${ }^{1,3,4}$, Jennifer NS Leung ${ }^{5}$, Kathy Leung ${ }^{1,2}$, Cheuk-Kwong Lee ${ }^{5, *}$, JS Malik Peiris ${ }^{1,3,4, *}$, Joseph T Wu ${ }^{1,2, *}$

${ }^{1}$ WHO Collaborating Centre for Infectious Disease Epidemiology and Control, School of Public Health, LKS Faculty of Medicine, The University of Hong Kong, Hong Kong SAR, China ${ }^{2}$ Laboratory of Data Discovery for Health $\left(D^{2} 4 H\right)$, Hong Kong Science Park, Hong Kong SAR, China ${ }^{3} \mathrm{HKU}$-Pasteur Research Pole, School of Public Health, The University of Hong Kong, Hong Kong SAR, China ${ }^{4}$ Centre for Immunology and Infection (C2i), Hong Kong Science Park, Hong Kong SAR, China ${ }^{5}$ Hong Kong Red Cross Blood Transfusion Service, Hospital Authority, Hong Kong SAR, China

* Cheuk-Kwong Lee, JS Malik Peiris and Joseph T Wu contributed equally as senior authors.

Corresponding author:

Kathy Leung, School of Public Health, LKS Faculty of Medicine, The University of Hong Kong, 1/F North Wing, Patrick Manson Building, 7 Sassoon Road, Pok Fu Lam, Hong Kong. Tel: + 8523917 6735; Email: ksmleung@hku.hk. 
medRxiv preprint doi: https://doi.org/10.1101/2021.12.05.21267330; this version posted December 7, 2021. The copyright holder for this preprint

(which was not certified by peer review) is the author/funder, who has granted medRxiv a license to display the preprint in perpetuity.

$$
\text { It is made available under a CC-BY-NC-ND } 4.0 \text { International license. }
$$

\begin{abstract}
Both inactivated vaccine (CoronaVac; Sinovac) and mRNA vaccine (Comirnaty/BNT162b2; FosunPharma/BioNTech) are available in Hong Kong's COVID-19 Vaccination Programme. We reported waning antibody levels by enzyme-linked immunosorbent assays (ELISA) and surrogate virus neutralization test (sVNT) among 850 fully vaccinated blood donors (i.e., received two doses). The BNT162b2 group's antibody levels remain over the $50 \%$ protection threshold within six months, and the CoronaVac's group's median antibody levels begin to fall below the $50 \%$ protection threshold two months after vaccination.
\end{abstract}


medRxiv preprint doi: https://doi.org/10.1101/2021.12.05.21267330; this version posted December 7, 2021. The copyright holder for this preprint (which was not certified by peer review) is the author/funder, who has granted medRxiv a license to display the preprint in perpetuity. It is made available under a CC-BY-NC-ND 4.0 International license .

The Hong Kong government launched its COVID-19 Vaccination Programme on 26 February 2021. The programme is free for all Hong Kong residents with both inactivated vaccine (CoronaVac; Sinovac) and mRNA vaccine (Comirnaty/BNT162b2; Fosun-Pharma/BioNTech) being available. As of 31 October 2021, 9,043,407 doses have been administered and over $60 \%(4,425,382)$ of the eligible population have received two doses [1].

As part of a community-based COVID-19 sero-epidemiological study, we recruited 14,169 healthy blood donors at the Hong Kong Red Cross Blood Transfusion Service from April 2020 to October 2021. Among these donors, 850 were fully vaccinated (at least 14 days after the second dose, according to the Hong Kong Centre for Health Protection) with either BNT162b2 or CoronaVac and provided their vaccination history. Of the 850 fully vaccinated blood donors, $593(69.8 \%)$ received two doses of BNT162b2 and $257(30.2 \%)$ received two doses of CoronaVac. The CoronaVac group was older than the BNT162b2 group (median age 48 vs 39, $p<0.001$ ). The duration from receiving the second dose of vaccine to the blood donation was shown in Supplementary table 1.

All samples collected were first tested using an enzyme-linked immunosorbent assay (ELISA), which detects antibodies to the receptor-binding domain (RBD) of the severe acute respiratory syndrome coronavirus 2 (SARS-CoV-2) spike protein [2]. ELISA-positive samples were further tested using surrogate virus neutralization test (SVNT), which measures neutralising antibodies that inhibit interaction between ACE-2 human cell surface receptor and SARS-CoV-2 spike protein RBD [3]. The manufacturers' recommended threshold for a positive sVNT test was $\geq 30 \%$ inhibition of signal. We arbitrarily assigned an sVNT signal inhibition percentage of $20 \%$ to ELISA-negative samples with no sVNT results, since we expect these samples to show low but non-zero result if they had been tested.

Participants were categorised by the vaccine they received, and the number of months between their vaccination and donation (from month 0 to month 6 ). The BNT162b2 group had a higher percentage of positive ELISA ( $99.2 \%$ vs. $73.2 \%, p<0.001)$ and sVNT $(99.0 \%$ vs. $70.4 \%, p<0.001)$ results than the CoronaVac group overall. The BNT162b2 vaccinees show a generally higher level of antibodies than the CoronaVac vaccinees in both ELISA (1.94 vs. $0.86, p<0.001)$ and SVNT ( $94 \%$ vs $39 \%, p<$ 0.001 ); this trend is observed from within a month after vaccination to five months after vaccination (Supplementary table 2).

Recent studies showed that a $50 \%$ plaque reduction neutralisation test $\left(\mathrm{PRNT}_{50}\right)$ titre of $1: 25.9$, which is approximately $20 \%$ of the mean convalescent neutralisation level, provides $50 \%$ protection against infection of SARS-CoV-2 [4]. Since PRNT 50 is correlated with sVNT results, we estimate a $50 \%$ protection threshold to be $45.3 \%$ inhibition in SVNT $[5,6]$. Although antibody levels decline over time for both groups, the BNT162b2 group's antibody levels remain well over the $50 \%$ protection threshold; the CoronaVac's group's median antibody levels begin to fall below the $50 \%$ protection threshold two months after vaccination (Supplementary table 3, Figure). We did not derive a protection threshold for ELISA since sVNT performs better in terms of test specificity and sensitivity [7].

There have been limited studies on waning antibody levels following CoronaVac vaccine $[8,9]$. Since antibody levels have been shown to be predictive of protection against SARS-CoV- 2 and other variants of concern, waning antibody levels with different COVID-19 vaccines should be taken into consideration when designing vaccination programmes $[3,4,10]$. Our study did not account for other mechanisms of immune protection such as T cell response, which might also be important in assessing vaccine protection against severe infections of SARS-CoV-2 [11-13]. We also did not account for the impact of virus variants which may have reduced susceptibility to neutralizing antibody by vaccines based on the original SARS-CoV-2. Thus, our estimates are likely to be over- 
medRxiv preprint doi: https://doi.org/10.1101/2021.12.05.21267330; this version posted December 7, 2021. The copyright holder for this preprint (which was not certified by peer review) is the author/funder, who has granted medRxiv a license to display the preprint in perpetuity. It is made available under a CC-BY-NC-ND 4.0 International license.

optimistic but provide a minimum estimate. More studies on vaccine-induced protection over time are needed to help formulate effective vaccination strategies. 

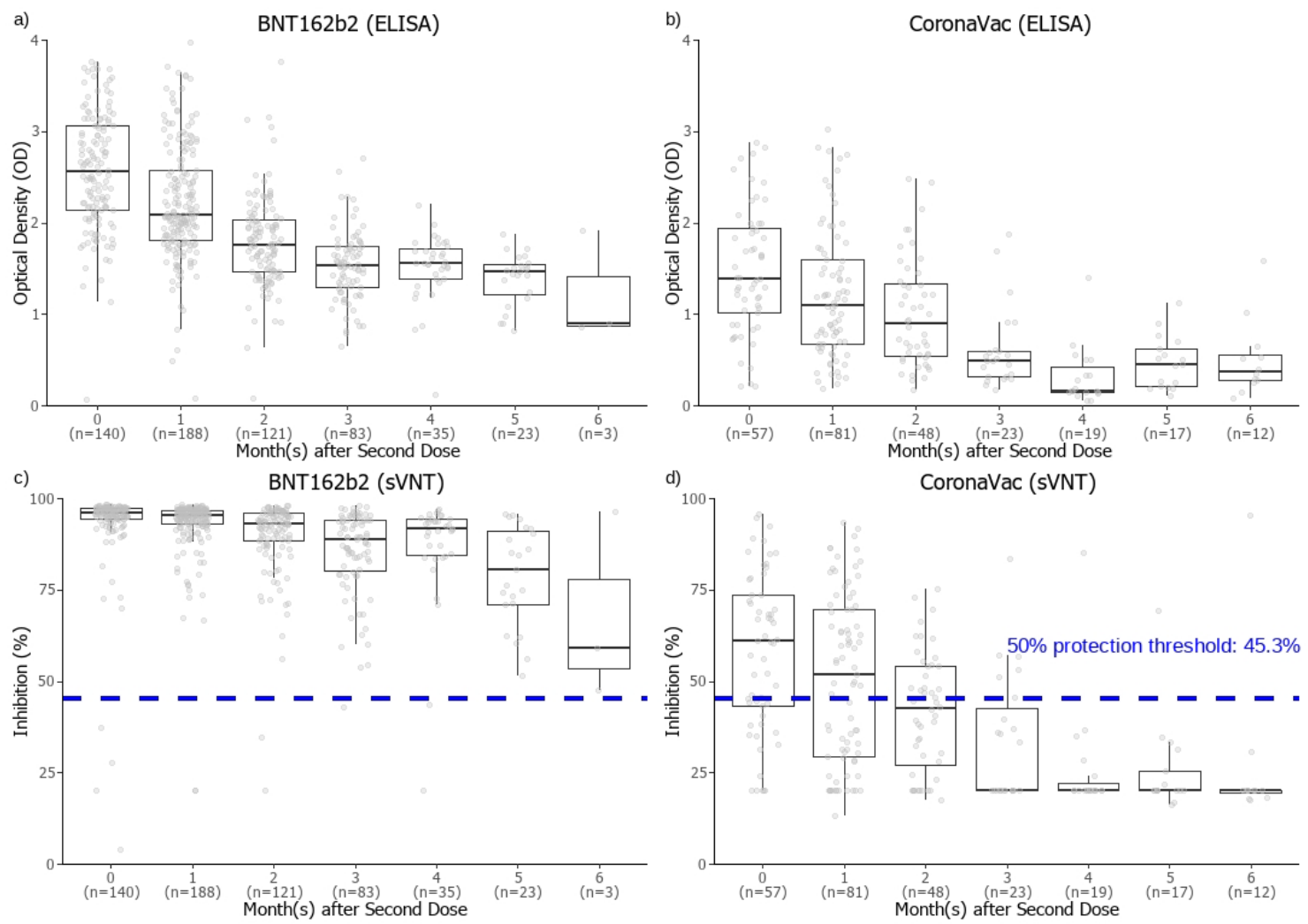

Figure. Antibody responses in Hong Kong blood donors from 14 days to 6 months after vaccination; enzyme-linked immunosorbent assay (ELISA) results for BNT162b2 vaccinees (A) and CoronaVac vaccinees (B), and surrogate virus neutralisation test (sVNT) results for BNT162b2 vaccinees (C) and CoronaVac vaccinees (D)*

* Lower and upper hinges of boxplot represent first and third quartiles (interquartile range), middle hinge represents median, upper and lower whiskers extend to 1.5 times the interquartile range. Outliers are data beyond the end of the whiskers. 


\section{Acknowledgements}

We would like to thank all participants from Causeway Bay, Sha Tin and Tsuen Wan Donation Centre of Hong Kong Blood Transfusion Service. We also would like to thank Ms Wing-Ching Ling and Ms Rita Lo from the Red Cross Blood Transfusion Service and Ms Miky Wong, Dr Di Liu and Ms Kitty YY Lau from the School of Public Health, University of Hong Kong for their technical support.

\section{Funding}

This research was supported by Health and Medical Research Fund (grant no.: COVID190126, CIDHKU2 and COVID19F05), Health and Medical Research Fund Research Fellowship Scheme (grant no.: 06200097), General Research Fund (grant no.: 17110020), and the AIR@InnoHK Programme from Innovation and Technology Commission of the Government of the Hong Kong Special Administrative Region. KL was supported by the Enhanced New Staff Start-up Research Grant from LKS Faculty of Medicine, The University of Hong Kong. The funders of the study had no role in study design, data collection, data analysis, data interpretation, or writing of the report. The corresponding author had full access to all the data in the study and had final responsibility for the decision to submit for publication.

\section{References}

1. The Government of Hong Kong Special Administrative Region. Hong Kong Vaccination Dashboard 2021 [Available from: https://www.covidvaccine.gov.hk/en/dashboard/.

2. Perera RA, Mok CK, Tsang OT, Lv H, Ko RL, Wu NC, et al. Serological assays for severe acute respiratory syndrome coronavirus 2 (SARS-CoV-2), March 2020. Eurosurveillance. 2020;25(16):2000421.

3. Perera RAPM, Ko R, Tsang OTY, Hui DSC, Kwan MYM, Brackman Cl, et al. Evaluation of a SARS-CoV-2 Surrogate Virus Neutralization Test for Detection of Antibody in Human, Canine, Cat, and Hamster Sera. Journal of Clinical Microbiology. 2021;59(2):e02504-20.

4. Khoury DS, Cromer D, Reynaldi A, Schlub TE, Wheatley AK, Juno JA, et al. Neutralizing antibody levels are highly predictive of immune protection from symptomatic SARS-CoV-2 infection. Nature Medicine. 2021;27(7):1205-11.

5. Lau EHY, Hui DSC, Tsang OTY, Chan W-H, Kwan MYW, Chiu SS, et al. Long-term persistence of SARS-CoV-2 neutralizing antibody responses after infection and estimates of the duration of protection. EClinicalMedicine. 2021;41.

6. Leung K, Jit M, Leung GM, Wu JT. Comparative effectiveness of allocation strategies of COVID-19 vaccines and antivirals against emerging SARS-CoV- 2 variants of concern in East Asia and Pacific region. medRxiv. 2021:2021.10.20.21265245.

7. Tan CW, Chia WN, Qin X, Liu P, Chen MIC, Tiu C, et al. A SARS-CoV-2 surrogate virus neutralization test based on antibody-mediated blockage of ACE2-spike protein-protein interaction. Nature Biotechnology. 2020;38(9):1073-8.

8. Zee JS, Lai KT, Ho MK, Leung AC, Fung L, Luk W, et al. Serological response to mRNA and inactivated COVID-19 vaccine in healthcare workers in Hong Kong: decline in antibodies 12 weeks after two doses. Hong Kong medical journal= Xianggang yi xue za zhi. 2021;27(5):380-3.

9. Pan H, Wu Q, Zeng G, Yang J, Jiang D, Deng X, et al. Immunogenicity and safety of a third dose, and immune persistence of CoronaVac vaccine in healthy adults aged $18-59$ years: interim results from a double-blind, randomized, placebo-controlled phase 2 clinical trial. medRxiv. 2021. 10. Cromer D, Steain M, Reynaldi A, Schlub TE, Wheatley AK, Juno JA, et al. Neutralising antibody titres as predictors of protection against SARS-CoV-2 variants and the impact of boosting: a meta-analysis. The Lancet Microbe. 
medRxiv preprint doi: https://doi.org/10.1101/2021.12.05.21267330; this version posted December 7, 2021. The copyright holder for this preprint

(which was not certified by peer review) is the author/funder, who has granted medRxiv a license to display the preprint in perpetuity.

It is made available under a CC-BY-NC-ND 4.0 International license.

11. Chen Y, Yin S, Tong X, Tao Y, Ni J, Pan J, et al. Dynamic SARS-CoV-2-specific B-cell and T-cell responses following immunization with an inactivated COVID-19 vaccine. Clinical Microbiology and Infection. 2021.

12. Geers D, Shamier MC, Bogers S, Hartog Gd, Gommers L, Nieuwkoop NN, et al. SARS-CoV-2 variants of concern partially escape humoral but not T cell responses in COVID-19 convalescent donors and vaccine recipients. Science Immunology. 2021;6(59):eabj1750.

13. Sahin U, Muik A, Vogler I, Derhovanessian E, Kranz LM, Vormehr M, et al. BNT162b2 vaccine induces neutralizing antibodies and poly-specific T cells in humans. Nature. 2021;595(7868):572-7. 


\section{Supplementary material}

This supplementary material is hosted by Eurosurveillance as supporting information alongside the article "Waning antibody levels after vaccination with mRNA BNT162b2 and inactivated CoronaVac COVID-19 vaccines in Hong Kong blood donors" on behalf of the authors who remain responsible for the accuracy and appropriateness of the content. The same standards for ethics, copyright, attributions and permissions as for the article apply. Supplements are not edited by Eurosurveillance and the journal is not responsible for the maintenance of any links or email addresses provided therein.

\section{Supplementary table 1. Characteristics of study cohort}

\begin{tabular}{|c|c|c|c|c|c|c|c|}
\hline & \multicolumn{2}{|c|}{$\begin{array}{c}\text { Overall } \\
(\mathrm{N}=850)\end{array}$} & \multicolumn{2}{|c|}{$\begin{array}{c}\text { BNT162b2 } \\
(n=593)\end{array}$} & \multicolumn{2}{|c|}{$\begin{array}{c}\text { CoronaVac } \\
(n=257)\end{array}$} & \multirow[t]{2}{*}{$p+$} \\
\hline & No. of donors & $\%$ of donors & No. of donors & $\%$ of donors & No. of donors & $\%$ of donors & \\
\hline Age group & & & & & & & $<0.001$ \\
\hline $12-19$ & 16 & $1.9 \%$ & 14 & $2.4 \%$ & 2 & $0.8 \%$ & \\
\hline $20-29$ & 137 & $16.1 \%$ & 127 & $21.4 \%$ & 10 & $3.9 \%$ & \\
\hline $30-39$ & 199 & $23.4 \%$ & 163 & $27.5 \%$ & 36 & $14.0 \%$ & \\
\hline $40-49$ & 243 & $28.6 \%$ & 153 & $25.8 \%$ & 90 & $35.0 \%$ & \\
\hline $50-59$ & 195 & $22.9 \%$ & 100 & $16.9 \%$ & 95 & $37.0 \%$ & \\
\hline $60-69$ & 60 & $7.1 \%$ & 36 & $6.1 \%$ & 24 & $9.3 \%$ & \\
\hline Gender & & & & & & & 0.025 \\
\hline Female & 387 & $45.5 \%$ & 285 & $48.1 \%$ & 102 & $39.7 \%$ & \\
\hline Male & 463 & $54.5 \%$ & 308 & $51.9 \%$ & 155 & $60.3 \%$ & \\
\hline Month(s) after vaccination & & & & & & & $<0.001$ \\
\hline $\mathbf{0}$ & 197 & $23.2 \%$ & 140 & $23.6 \%$ & 57 & $22.2 \%$ & \\
\hline 1 & 269 & $31.6 \%$ & 188 & $31.7 \%$ & 81 & $31.5 \%$ & \\
\hline 2 & 169 & $19.9 \%$ & 121 & $20.4 \%$ & 48 & $18.7 \%$ & \\
\hline 3 & 106 & $12.5 \%$ & 83 & $14.0 \%$ & 23 & $8.9 \%$ & \\
\hline 4 & 54 & $6.4 \%$ & 35 & $5.9 \%$ & 19 & $7.4 \%$ & \\
\hline 5 & 40 & $4.7 \%$ & 23 & $3.9 \%$ & 17 & $6.6 \%$ & \\
\hline 6 & 15 & $1.8 \%$ & 3 & $0.5 \%$ & 12 & $4.7 \%$ & \\
\hline
\end{tabular}

† Tested using Fisher's exact test. 
Supplementary table 2. ELISA and sVNT results from 14 days to 6 months after vaccination, comparison between BNT162b2 and CoronaVac*

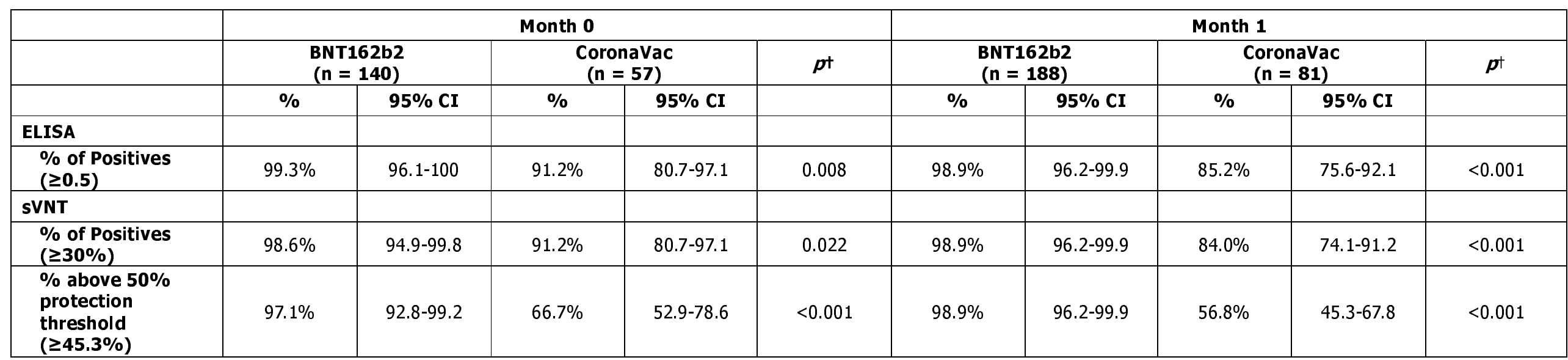

\begin{tabular}{|c|c|c|c|c|c|c|c|c|c|c|}
\hline & \multicolumn{5}{|c|}{ Month 2} & \multicolumn{5}{|c|}{ Month 3} \\
\hline & \multicolumn{2}{|c|}{$\begin{array}{l}\text { BNT162b2 } \\
(n=121)\end{array}$} & \multicolumn{2}{|c|}{$\begin{array}{c}\text { CoronaVac } \\
(n=48)\end{array}$} & \multirow[t]{2}{*}{$p+$} & \multicolumn{2}{|c|}{$\begin{array}{c}\text { BNT162b2 } \\
(\mathrm{n}=83)\end{array}$} & \multicolumn{2}{|c|}{$\begin{array}{c}\text { CoronaVac } \\
(n=23)\end{array}$} & \multirow[t]{2}{*}{$p t$} \\
\hline & $\%$ & $95 \% \mathrm{CI}$ & $\%$ & $95 \% \mathrm{CI}$ & & $\%$ & $95 \% \mathrm{CI}$ & $\%$ & $95 \%$ CI & \\
\hline \multicolumn{11}{|l|}{ ELISA } \\
\hline $\begin{array}{l}\text { \% of Positives } \\
(\geq 0.5)\end{array}$ & $99.2 \%$ & $95.5-100$ & $79.2 \%$ & $65.0-89.5$ & $<0.001$ & $100 \%$ & $95.7-100$ & $47.8 \%$ & $26.8-69.4$ & $<0.001$ \\
\hline \multicolumn{11}{|l|}{ sVNT } \\
\hline $\begin{array}{l}\text { \% of Positives } \\
(\geq 30 \%)\end{array}$ & $99.2 \%$ & $95.5-100$ & $77.1 \%$ & $62.7-88.0$ & $<0.001$ & $100 \%$ & $95.7-100$ & $47.8 \%$ & $26.8-69.4$ & $<0.001$ \\
\hline $\begin{array}{l}\text { \% above } 50 \% \\
\text { protection } \\
\text { threshold } \\
(\geq \mathbf{4 5 . 3 \% )}\end{array}$ & $98.3 \%$ & $94.2-99.8$ & $43.8 \%$ & $29.5-58.8$ & $<0.001$ & $98.8 \%$ & $93.5-100$ & $26.1 \%$ & $10.2-48.4$ & $<0.001$ \\
\hline
\end{tabular}




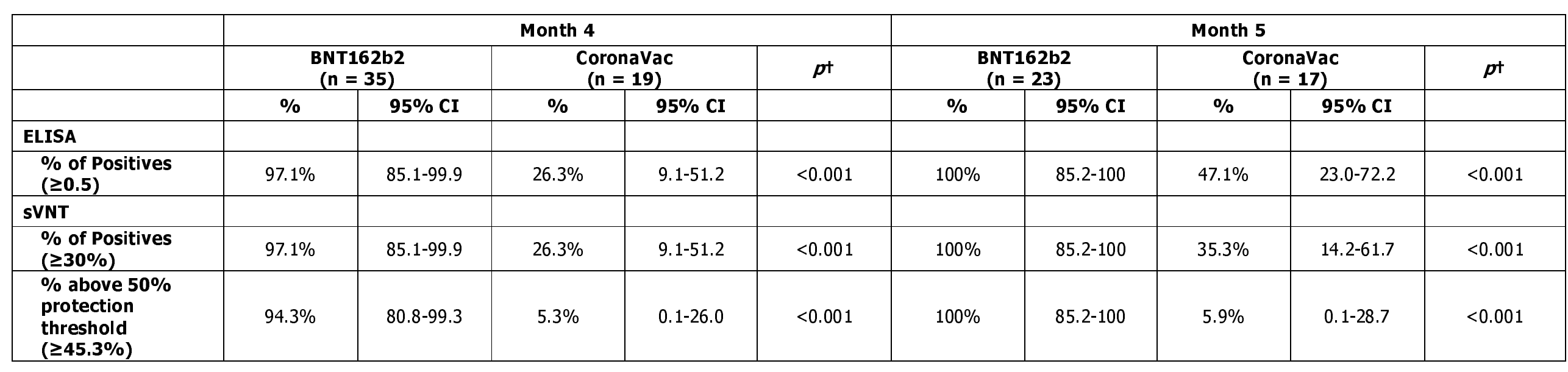

\begin{tabular}{|c|c|c|c|c|c|c|c|c|c|c|}
\hline & \multicolumn{5}{|c|}{ Month 6} & \multicolumn{5}{|c|}{ Overall } \\
\hline & \multicolumn{2}{|c|}{$\begin{array}{c}\text { BNT162b2 } \\
(n=3)\end{array}$} & \multicolumn{2}{|c|}{$\begin{array}{c}\text { CoronaVac } \\
(n=12)\end{array}$} & \multirow[t]{2}{*}{$p+$} & \multicolumn{2}{|c|}{$\begin{array}{c}\text { BNT162b2 } \\
(n=593)\end{array}$} & \multicolumn{2}{|c|}{$\begin{array}{c}\text { CoronaVac } \\
(n=257)\end{array}$} & \multirow[t]{2}{*}{$p+$} \\
\hline & $\%$ & $95 \%$ CI & $\%$ & $95 \%$ CI & & $\%$ & $95 \% \mathrm{CI}$ & $\%$ & $95 \% \mathrm{CI}$ & \\
\hline \multicolumn{11}{|l|}{ ELISA } \\
\hline $\begin{array}{l}\text { \% of Positives } \\
(\geq 0.5)\end{array}$ & $100 \%$ & $29.2-100$ & $41.7 \%$ & $15.2-72.3$ & 0.2 & $99.2 \%$ & $98.0-99.7$ & $73.2 \%$ & $67.3-78.5$ & $<0.001$ \\
\hline \multicolumn{11}{|l|}{ SVNT } \\
\hline $\begin{array}{l}\% \text { above } 50 \% \\
\text { protection } \\
\text { threshold } \\
(\mathbf{2 5 . 3} \%)\end{array}$ & $100 \%$ & $29.2-100$ & $8.3 \%$ & $0.2-38.5$ & 0.009 & $98.1 \%$ & $96.7-99.1$ & $44 . .4 \%$ & $38.2-50.7$ & $<0.001$ \\
\hline
\end{tabular}

* $95 \%$ confidence interval calculated from binomial distribution using the Clopper-Pearson method.

† Tested using Fisher's exact test. 
Supplementary table 3a. ELISA and sVNT results from 14 days to 6 months after vaccination with BNT162b2*

\begin{tabular}{|c|c|c|c|c|c|c|c|c|c|c|c|c|c|c|c|}
\hline & \multicolumn{15}{|c|}{ BNT162b2 } \\
\hline & \multicolumn{2}{|c|}{$\begin{array}{c}\text { Month 0 } \\
(n=140)\end{array}$} & \multicolumn{2}{|c|}{$\begin{array}{c}\text { Month 1 } \\
(n=188)\end{array}$} & \multicolumn{2}{|c|}{$\begin{array}{c}\text { Month } 2 \\
(n=121)\end{array}$} & \multicolumn{2}{|c|}{$\begin{array}{l}\text { Month } 3 \\
(n=83)\end{array}$} & \multicolumn{2}{|c|}{$\begin{array}{l}\text { Month } 4 \\
(n=35)\end{array}$} & \multicolumn{2}{|c|}{$\begin{array}{l}\text { Month } 5 \\
(n=23)\end{array}$} & \multicolumn{2}{|c|}{$\begin{array}{c}\text { Month } 6 \\
(n=3)\end{array}$} & \multirow[t]{2}{*}{$p+$} \\
\hline & $\%$ & $95 \% \mathrm{CI}$ & $\%$ & $95 \% \mathrm{CI}$ & $\%$ & $95 \% \mathrm{CI}$ & $\%$ & $95 \% \mathrm{CI}$ & $\%$ & $95 \% \mathrm{CI}$ & $\%$ & $95 \% \mathrm{CI}$ & $\%$ & $95 \% \mathrm{CI}$ & \\
\hline ELISA & & & & & & & & & & & & & & & \\
\hline $\begin{array}{c}\text { \% of } \\
\text { Positives } \\
(\geq 0.5)\end{array}$ & $99.3 \%$ & $96.1-100$ & $98.9 \%$ & $96.2-99.9$ & $99.2 \%$ & $95.5-100$ & $100 \%$ & $95.7-100$ & $97.1 \%$ & 85.1-99.9 & $100 \%$ & $85.2-100$ & $100 \%$ & $29.2-100$ & 0.7 \\
\hline sVNT & & & & & & & & & & & & & & & \\
\hline $\begin{array}{c}\text { \% of } \\
\text { Positives } \\
(\geq 30 \%)\end{array}$ & $98.6 \%$ & $94.9-99.8$ & $98.9 \%$ & $96.2-99.9$ & $99.2 \%$ & $95.5-100$ & $100 \%$ & $95.7-100$ & $97.1 \%$ & 85.1-99.9 & $100 \%$ & $85.2-100$ & $100 \%$ & $29.2-100$ & 0.7 \\
\hline $\begin{array}{l}\text { \% above } \\
50 \% \\
\text { protection } \\
\text { threshold } \\
(\geq 45.3 \%)\end{array}$ & $97.1 \%$ & $92.8-99.2$ & $98.9 \%$ & $96.2-99.9$ & $98.3 \%$ & $94.2-99.8$ & $98.8 \%$ & $93.5-100$ & $94.3 \%$ & $80.8-99.3$ & $100 \%$ & $85.2-100$ & $100 \%$ & $29.2-100$ & 0.2 \\
\hline
\end{tabular}

* $95 \%$ confidence interval calculated from binomial distribution using the Clopper-Pearson method.

† Tested using Fisher's exact test.

\section{Supplementary table 3b. ELISA and sVNT results from 14 days to 6 months after vaccination with CoronaVac*}

\begin{tabular}{|c|c|c|c|c|c|c|c|c|c|c|c|c|c|c|c|}
\hline & \multicolumn{15}{|c|}{ CoronaVac } \\
\hline & \multicolumn{2}{|c|}{$\begin{array}{l}\text { Month } 0 \\
(n=57)\end{array}$} & \multicolumn{2}{|c|}{$\begin{array}{l}\text { Month 1 } \\
(n=81)\end{array}$} & \multicolumn{2}{|c|}{$\begin{array}{l}\text { Month } 2 \\
(n=48)\end{array}$} & \multicolumn{2}{|c|}{$\begin{array}{l}\text { Month } 3 \\
(n=23)\end{array}$} & \multicolumn{2}{|c|}{$\begin{array}{l}\text { Month } 4 \\
(n=19)\end{array}$} & \multicolumn{2}{|c|}{$\begin{array}{l}\text { Month } 5 \\
(n=17)\end{array}$} & \multicolumn{2}{|c|}{$\begin{array}{l}\text { Month } 6 \\
(n=12)\end{array}$} & \multirow[t]{2}{*}{$p t$} \\
\hline & $\%$ & $95 \%$ CI & $\%$ & $95 \% \mathrm{CI}$ & $\%$ & $95 \% \mathrm{CI}$ & $\%$ & $95 \%$ CI & $\%$ & $95 \%$ CI & $\%$ & $95 \% \mathrm{CI}$ & $\%$ & $95 \%$ CI & \\
\hline \multicolumn{16}{|l|}{ ELISA } \\
\hline $\begin{array}{l}\text { \% of Positives } \\
(\geq 0.5)\end{array}$ & $91.2 \%$ & 80.7-97.1 & $85.2 \%$ & $75.6-92.1$ & $79.2 \%$ & $65.0-89.5$ & $47.8 \%$ & $26.8-69.4$ & $26.3 \%$ & $9.1-51.2$ & $47.1 \%$ & $23.0-72.2$ & $41.7 \%$ & $15.2-72.3$ & $<0.001$ \\
\hline \multicolumn{16}{|l|}{ sVNT } \\
\hline $\begin{array}{l}\text { \% of Positives } \\
(\geq \mathbf{3 0} \%)\end{array}$ & $91.2 \%$ & $80.7-97.1$ & $84.0 \%$ & $74.1-91.2$ & $77.1 \%$ & $62.7-88.0$ & $47.8 \%$ & $26.8-69.4$ & $26.3 \%$ & $9.1-51.2$ & $35.3 \%$ & $14.2-61.7$ & $16.7 \%$ & $2.1-48.4$ & $<0.001$ \\
\hline $\begin{array}{l}\text { \% above } 50 \% \\
\text { protection } \\
\text { threshold } \\
(\geq \mathbf{4 5 . 3} \%)\end{array}$ & $66.7 \%$ & $52.9-78.6$ & $56.8 \%$ & $45.3-67.8$ & $43.8 \%$ & $29.5-58.8$ & $26.1 \%$ & $10.2-48.4$ & $5.3 \%$ & $0.1-26.0$ & $5.9 \%$ & $0.1-28.7$ & $8.3 \%$ & $0.2-38.5$ & 0.002 \\
\hline
\end{tabular}

* $95 \%$ confidence interval calculated from binomial distribution using the Clopper-Pearson method.

† Tested using Fisher's exact test. 